\title{
Kosttilskudd forebygger ikke prostatakreft
}

\author{
Risiko for prostatakreft blir ikke redu- \\ sert ved bruk av vitamin $E$, vitamin $C$ \\ eller selen som kosttilskudd. Det viser \\ to store randomiserte studier fra USA.
}

I en randomisert, dobbeltblindet, placebokontrollert studie der 14600 mannlige amerikanske leger ble fulgt $\mathrm{i}$ ti år, ga tilskudd av $400 \mathrm{IU}$ vitamin $\mathrm{C}$ hver annen dag og 500 $\mathrm{mg}$ vitamin $\mathrm{C}$ daglig ingen effekt på forekomsten av prostatakreft (1). En annen randomisert, placebokontrollert studie omfattet 35500 menn fra USA, Canada og Puerto Rico. Her var konklusjonen at $200 \mu \mathrm{g}$ selen daglig alene eller i kombinasjon med 400 IU vitamin $E$ heller ikke hadde effekt på forekomsten av prostatakreft (2).

- Både eksperimentelle og observasjonelle studier har tidligere vist at ulike komponenter i kosten kan påvirke risikoen for prostatakreft. At dette ikke bekreftes i disse to studiene, har flere mulige forklaringer, sier forsker Anette Hjartåker ved Avdeling for årsaks- og karsinogeneseforskning ved Kreftregisteret.

- Observasjonsstudier har en rekke metodologiske utfordringer som svekker muligheten til å gi sikre konklusjoner. På den annen side viser observasjonsstudiene

\section{Urinprøve for deteksjon av prostatakreft?}

\section{En metabolitt kalt sarkosin er høyere i urin og plasma fra prostatakreft- pasienter enn blant friske menn.}

Forskere har ved å benytte kromatografibasert massespektroskopi nå isolert 1126 metabolitter fra prøver fra prostatavev, serum og urin (1). De identifiserte 87 metabolitter hvis mengde var forskjellig hos menn med prostatakreft sammenliknet med friske menn.

Nivået av metabolitten sarkosin $(\mathrm{N}$ metylglysin) var høyere jo mer avansert kreftsykdommen var, og kunne påvises i urin og plasma. Forskergruppen gjorde så celleforsøk og viste at ved å hemme danningen av sarkosin ble prostatakreftceller mindre invasive. Ved å addere sarkosin til benigne epitelceller fra prostata fikk cellene invasive egenskaper.

- Dette er en veldig interessant studie, sier overlege Wolfgang Lilleby ved Oslo universitetssykehus, Radiumhospitalet. Man har også tidligere gjort undersøkelser med tanke på urinprøve som screeningmateriale, og proteinet PCA3 er et annet kandidat-

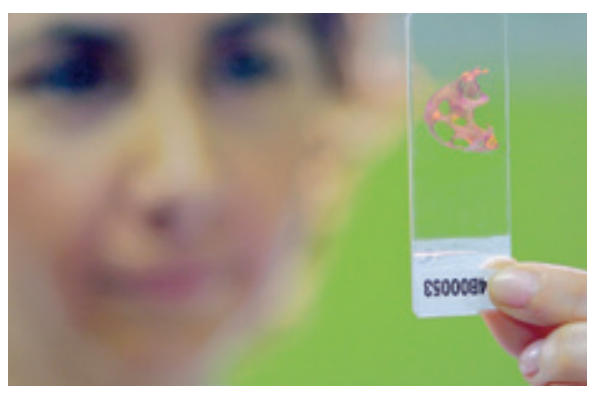

Illustrasjonsfoto AGE Fotostock/GV-Press/ NordicPhotos

effekten av det vi faktisk spiser og ikke effekten av enkeltmolekyler. Per i dag er det ikke grunnlag for å anbefale kosttilskudd for å forebygge prostatakreft, sier Hjartåker.

\section{Are Brean}

are.brean@siv.no

Tidsskriftet

\section{Litteratur}

1. Gaziano JM, Robert JG, Christen WG et al. Vitamins $E$ and $C$ in the prevention of prostate and total cancer in men: The Physicians' Health Study II Randomized Controlled Trial. JAMA 2009; 301 : 52-62.

2. Lippman SM, Klein EA, Goodman PJ et al. Effect of selenium and vitamin $E$ on risk of prostate cancer and other cancers: the Selenium and Vitamin E Cancer Prevention Trial (SELECT). JAMA 2009. 301: $39-51$

\section{Ulik diett - samme effekt}

En studie publisert i New England Journal of Medicine $(2009 ; 360$ : 859-73) viser at om en diett består av mest karbohydrater, fett eller proteiner har lite å si for om en person klarer å gå ned i vekt. Mer enn 800 overvektige personer ble randomisert til å følge én av fire ulike dietter. Alle skulle sikre et kaloriunderskudd på $750 \mathrm{kcal} / \mathrm{dag}$. men varierte i forhold til hvilke makronæringsstoffer som dominerte. Etter seks måneder var gjennomsnittlig vektreduksjon $6 \mathrm{~kg}$ for alle gruppene. Også etter to år var vekttapet det samme, men da hadde de fleste begynt å legge på seg igjen.

Forfatteren av en lederartikkel i samme nummer (s. 923-4) skriver at selv med så motiverte grupper med så god oppfølging er det få som går betydelig ned i vekt, og få som klarer å holde dietten. Derfor trenger vi ikke flere slike studier. Antakelig er samfunnsrettede tiltak bedre egnet for å redusere forekomsten av overvekt.

\section{Brannrelaterte dødsfall}

I en studie i The Lancet har man funnet at $2 \%$ av alle dødsfall i India i 2001 var brannrelaterte, og hele $65 \%$ av disse dødsfallene var blant kvinner i alderen 15-34 år (DOI: 10.1016/S0140-6736(09)60235-X). Forfatterne gjorde en retrospektiv analyse av data fra sykehus i urbane områder og spørreundersøkelser fra rurale områder.

Studien viste at det var over 163000 brannrelaterte dødsfall i 2001, som er seks ganger høyere enn antallet som er rapportert av politiet. Gjennomsnittlig ratio av brannrelaterte dødsfall blant unge kvinner og unge menn var $3: 1$.

Forfatterne mener at det høye antallet av brannrelaterte dødsfall blant unge kvinner kommer av felles årsaker, som kjøkkenulykker, selvmord og kvinnemishandling.

protein (2). En markør som kan skille klinisk signifikant prostatakreft fra prostatakreft som aldri vil gi seg til kjenne klinisk, ville være et svært viktig funn.

- Resultatene fra cellestudiene tyder på at i tillegg til at sarkosin kan egne seg som en markør for deteksjon av prostatakreft, kan det også være et aktuelt mål for terapi. Nivået av sarkosin kan påvirkes gjennom kostholdet, noe som gjør funnet ekstra spennende. Det gjenstår selvsagt mye arbeid før disse nye resultatene eventuelt kan implementeres i daglig praksis, sier Lilleby.

\section{Åslaug Helland \\ aslaug.helland@gmail.com \\ Tidsskriftet}

\section{Litteratur}

Sreekumar A, Poisson LM, Rajendiran TM et al. Metabolomic profiles delineate potential role for sarcosine in prostate cancer progression. Nature 2009; 457: 910-5

2. Haese A, de la Taille A, van Poppel $\mathrm{H}$ et al. Clinical utility of the PCA3 urine assay in European men scheduled for repeat biopsy. Eur Urol 2008; 54: $1081-8$.

\section{Gangferdigheter og multippel sklerose}

Fampridin bedrer gangferdigheter blant noen pasienter med multippel sklerose og er godt tolerert, viser en fase 3-studie i The Lancet $(2009 ; 373: 732-8)$.

301 pasienter med multippel sklerose ble randomisert til å få enten fampridin (10 $\mathrm{mg}$ to ganger daglig) eller placebo i 14 uker. Forskerne evaluerte hvor lang tid det tok pasientene å gå en viss distanse etter to uker og hver fjerde uke deretter. De målte også pasientenes oppfatning av gangvanskeligheter ved bruk av en skala (MSWS-12).

Antall pasienter som oppnådde en høyere gangfart under behandling enn før behandling var signifikant høyere i fampridingruppen $(78 / 224,35 \%)$ sammenliknet med placebogruppen (6/72, $8 \%)$. Bedring i gangfart var $25,5 \%$ i fampridingruppen sammenliknet med 4,7\% i kontrollgruppen. Sammenliknet med kontrollgruppen oppfattet pasientene som fikk fampridin også at gangvanskelighetene var redusert. 